\title{
Florestas urbanas \\ e os serviços ambientais associados à produção de resíduos
}

\author{
Demóstenes Ferreira da Silva Filho \\ Escola Superior de Agricultura Luiz de Queiroz - USP, Professor livre-docente \\ desilvafilho@gmail.com
}

\section{RESUMO}

As cidades, cada vez mais, necessitam de árvores de bom porte e de sombra para utilizar bem os serviços baseados na natureza, em busca de um equilíbrio ou adaptação para com eventos extremos, como as ondas de calor ou de frio. Contudo, ao conservar árvores maduras, em locais mal projetados as árvores correm risco e algumas chegam a cair e causar desserviços quando atingem alvos como carros, casas e pessoas. Ao desenvolver técnicas adequadas para cuidar dessas árvores e ao examinar esse valioso componente arbóreo, por meio de instrumentos de alta precisão, pode-se chegar a necessidade de substituição gerando resíduos importantes. Tais resíduos, muitas vezes são excelentes recursos que ao serem aproveitados como movelaria, cobertura morta ou por meio de compostagem, podem gerar mais benefícios ambientais como a imobilização de carbono e promoção da economia circular. Cabe a sociedade estimular o aproveitamento desses resíduos por meio de políticas públicas como a diminuição de taxas para disposição e auxílio no transporte. Além disso é necessário conhecer melhor o patrimônio arbóreo, sua diversidade e sua velocidade de crescimento após podas. Tais podas não devem ser feitas apenas para limitar as árvores, mas serem reais instrumentos para garantir o bom desenvolvimento e segurança para maximizar benefícios e evitar acidentes.

Palavras-chave: cobertura arbórea, gestão do verde urbano, silvicultura urbana.

\begin{abstract}
Cities increasingly need good-sized trees and shade to make good use of nature-based services, in search of balance or adaptation to extreme events, such as hot or cold waves. However, when conserving mature trees, in poorly designed locations, trees are at risk and some even fall and cause disservice when they hit targets such as cars, houses and people. By developing appropriate techniques to care for these trees and by examining this valuable tree component, using high-precision instruments, the need for replacement can be generated, generating important waste. Such residues are often excellent resources that, when used as furniture, mulch or through composting, can generate more environmental benefits such as carbon immobilization and promotion of the circular economy. It is up to society to encourage the use of this waste through public policies such as the reduction of fees for disposal and aid in transportation. In addition, it is necessary to better understand the tree heritage, its diversity, and its speed of growth after pruning. Such pruning should not only be done to limit trees but be real instruments to ensure good development and safety to maximize benefits and prevent accidents.
\end{abstract}

Keywords: tree cover, urban green management, urban forestry. 